\title{
ANTI-FUNGAL AND ANTI-TERMITE ACTIVITY OF EXTRACTIVES COMPOUNDS FROM THERMALLY MODIFIED ASH WOODS
}

\author{
Kévin Candelier $^{1,2, \$}$, Marie-France Thévenon ${ }^{1,2}$, Robert Collet $^{3}$, Philippe Gérardin $^{4}$, Stéphane Dumarçay ${ }^{4}$
}

\begin{abstract}
Thermal modification of wood is a promising alternative to chemical and biocidal modification processes, increasing the biological durability and dimensional stability of wood. However, the wood-decay resistance properties of heat-treated wood are still not well known. The main objective of this study was to determine the biological resistance of heat-treated ash wood, and assess the antifungal and anti-termite activity of extractive compounds from heat-treated ash woods, depending on the intensity of the modification process ( 2 hours at $170,200,215,228\left({ }^{\circ} \mathrm{C}\right)$ - steam pressure). Untreated and heat-treated wood samples were extracted with water or acetone. The extracts were then used to determine inhibition effectiveness against white-rot (Trametes versicolor) and brown-rot (Rhodonia placenta) fungi. Whatman papers impregnated with extractives were used to evaluate the inhibition of termite feeding. Lastly, the extractives were analyzed by Gas Chromatography - Mass Spectrometry (GC-MS) and compared for their level of anti-termite and antifungal activity. The results showed that the degree of antifungal activity of these extracts depended on the solvent used during the extraction process and varied depending on heat treatment intensity. The extracts were more effective against brown-rot than white-rot fungi. However, the anti-termite activity of heat-treated ash wood extracts was not really significant. A GC-MS analysis showed that the main share of the extractives in untreated wood was removed. In addition, new chemical elements were generated by the thermal degradation of wood polymers (lignin and hemicelluloses), including aliphatic acids, monosaccharides and other products resulting from their dehydration reaction. The most abundant element was syringaldehyde, from lignin derived compounds, which might explain the antifungal activities of thermally treated ash wood extracts.
\end{abstract}

Keywords: Antifungal activity, extractive compounds, Fraxinus spp., heat treatment, termite resistance.

\section{INTRODUCTION}

Ash (Fraxinus spp.) is a significant hardwood resource largely used in the European wood industry. Given its very weak resistance to decay and insects, this timber is naturally in appropriate for class 3 use (EN 350 CEN 2016). Ash wood materials therefore need to be treated with biocide additives for outdoor use (Candelier et al. 2017, Gérard et al. 2017). Industrial wood protection methods usually focus on ways of impregnating active formulations containing biocides. However, ash wood is only a moderately treatable timber for both its sap and heartwood (EN 350 CEN 2016, Gérard et al. 2017). In addition, due to their impact on human health, these chemicals are a subject of environmental pressures, which will restrict their use in the near future (Schultz et al. 2007). The Implementation of EU Environmental Legislation in recent years has resulted in the development of non-biocidal alternatives, such as thermal modification (Sandberg and Kutnar 2016), chemical impregnation (Gérardin 2016, Mantanis 2017, Guo et al. 2018), or a combination of the two (Salman et al. 2016, Sandberg et al. 2017). Using antagonistic microorganisms, combined or not with biochemicals, is also considered as a

\footnotetext{
${ }^{1}$ French Agricultural Research Centre for International Development CIRAD, UPR BioWooEB, Montpellier, France. ${ }^{2}$ BioWooEB, University of Montpellier, CIRAD, Montpellier, France.

${ }^{3} \mathrm{LaBoMaP}$, Arts et Métiers ParisTech, Cluny, France.

${ }^{4}$ LERMAB, Faculté des Sciences et Technologies, Lorraine University, Vandœuvre-lès Nancy, France.

•Corresponding author: kevin.candelier@cirad.fr

Received: 29.01.2019 Accepted: 11.02.2020
} 
promising ecofriendly way of protecting wood: (i) biocontrol microorganisms consume the available nutrients and produce biochemical compounds that are toxic and/or repellent to fungal decay and, (ii) the biochemical compounds include cell wall-degrading enzymes, siderophores, chelating iron and other antibiotics. This last wood preservation method is not yet industrialized and requires additional studies, especially regarding the environmental impact of these formulations (Susi et al. 2011).

On the other hand, thermal treatment of wood, using slow pyrolysis in an inert atmosphere, has been widely studied and has now been industrially developed around the world, mainly to increase wood durability against fungi in line with the process parameters (Calonego et al. 2010, Candelier et al. 2016). According to the literature (Kamdem et al. 2002, Weiland and Guyonnet 2003), the improved resistance of heat-treated wood material to decay can be explained by the following four assumptions, all derived from chemical modifications of wood cell wall polymers due to their thermal degradation (Tjeerdsma and Militz 2005, Yildiz et al. 2006, Inari et al. 2007).

(i) The hydrophobic behavior of wood is increased, thus limiting water sorption within the material and reducing any fungal growth. This improved hydrophobicity reduces the capillary transfer of water into the thermally modified wood and thus limits fungal growth by removing the optimum conditions for its development (due to lack of water). In addition, heat-treated wood has a lower Fiber Saturation Point (FSP) than untreated wood, leading to better resistance to rot fungi (Weiland and Guyonnet 2003, Hakkou et al. 2006).

(ii) Wood polymers are modified and the enzymes involved in the fungal degradation of wood do not recognize it anymore as such. Firstly, the changes in lignin chemical composition prevent fungal enzymes from recognizing and attacking specific target molecules (Vallet et al. 2001, Lekounougou et al. 2009). Secondly, changes in the ligneous polymer network also seem to play a role in fungal inhibition. The improved resistance of modified wood to decay is mainly due to possible crosslinking between lignin and certain molecules derived from wood thermal degradation, such as furfural (Weiland and Guyonnet 2003). Such modifications lead to a substrate that is not recognized by the fungal enzyme system, resulting in an undecayed material (Hakkou et al. 2006). Moreover, cellulose may undergo an esterification reaction, due to the acetic acid generated during the thermal degradation of hemicelluloses (Tjeerdsma and Militz 2005, Gao et al. 2016).

(iii) Hemicelluloses are the main wood component degraded by thermal modification, inducing a significant loss in potential nutrients for fungal growth (Hakkou et al. 2006, Altgen et al. 2019). The chemical modification of polysaccharides is responsible for improving resistance to wood decay, but cannot be the only factor, as lignin is also an important source of nutrients for white-rot fungi (Lekounougou et al. 2009).

(iv) New extractive, fungicidal substances are generated by wood thermal degradation and can serve to prevent decay. In fact, some extracts from heat-treated beech, poplar and maritime pine are already known to have antifungal activities (Kamdem et al. 2000, Peters et al. 2009, Lovaglio et al. 2017). However, other studies showed that improvement in the resistance of beech wood to decay does not appear to be due to new extractible compounds formed during thermal treatment. Hakkou et al. (2006) reported that the new extractive compounds produced during heat treatment of beech wood, carried out between $200^{\circ} \mathrm{C}$ and $280{ }^{\circ} \mathrm{C}$, only had a slight effect on the heat-treated wood against Trametes versicolor. Kamdem et al. (2002) found similar results in a study focusing on heat-treated pine and spruce wood samples extracted with water and organic solvents.

The extractive content of heat-treated wood increased when treatment was carried out at low temperatures and decreased with treatment carried out at higher temperatures $\left(>220^{\circ} \mathrm{C}\right)$. Most of the raw extractives disappeared and new compounds, such as anhydrosugars, mannosan, galactosan, levoglucosan and two C5 anhydrosugars, were generated. Syringaldehyde, sinapaldehyde and syringic acid appeared to be the products formed in the largest amounts, all of which came from lignin degradation (Esteves et al. 2008). This hypothesis regarding the formation of new extractives and their role in heat-treated wood durability therefore remains to be confirmed.

The resistance of thermally modified wood to termites has also been studied. Contrary to fungal resistance, the influence of heat treatment on wood resistance to termites appeared to be more variable depending on the processing conditions and wood species. In many cases, resistance to termites was random and, in some cases, even reduced (Doi et al. 1998, Momohara et al. 2003, Nunes et al. 2004, Sivrikaya et al. 2015, Salman et al. 2016). Some studies revealed that thermally modified wood had lower termite resistance than untreated wood (Sivrikaya et al. 2015, Salman et al. 2016, Salman et al. 2017). Generally, termite survival levels reveal an effect of thermal treatment on the biology of these insects. Termite survival rates remained virtually constant for treatments carried out at a low temperature $\left(180^{\circ} \mathrm{C}\right.$ to $\left.210^{\circ} \mathrm{C}\right)$ and were lower for higher treatment 
temperatures. Treatments over $200{ }^{\circ} \mathrm{C}$ induced crucial modifications to the wood material, possibly reducing suitability for termites (Candelier et al. 2017). As heat-treated wood is consumed when exposed to termites, the toxicity of ingested components may be the reason for the higher mortality rate observed (Surini et al. 2012) when treatments are carried out at high intensities (temperature - duration). In addition, when heat-treated and untreated control wood samples were exposed side-by-side (choice test), termites preferred to attack the untreated wood samples (Nunes et al. 2004).

In some cases, when the thermal modification process was carried out under optimum conditions, heat treatment enabled low natural durability timbers to be used by making them more resistant to decay, allowing them to be used in use classes 2 and 3 (use class 4 being excluded due to the occurrence of soft rots) (EN 335 CEN 2013), thus up-grading their economic value (Kamdem et al. 2002). These improved biological properties conferred to the wood by chemical modifications have a negative impact on the mechanical resistance of heat-treated wood (Dilik and Hiziroglu 2012, De Oliveira-Araújo et al. 2016). Surface hardness seems to be slightly enhanced, while other characteristics, such as bending and compression strengths, stiffness and shear strength, are considerably weakened depending on the kind of thermal processes and treatment intensities used (Boonstra et al. 2008, Hannouz et al. 2015).

The objective of this study was to investigate the antifungal and anti-termite activities of extracts from thermally modified ash wood depending on different treatment intensities. In order to ensure the reproducibility of the thermal treatment processes, as well as the quality of the treated wood products, the heat treatments were carried out under monitored conditions, using different heating temperatures $(170,200,200,215$ and 228 $\left.\left({ }^{\circ} \mathrm{C}\right)\right)$ and a fixed residence time $(2 \mathrm{~h})$.

\section{MATERIALS AND METHODS}

\section{Wood samples}

Untreated ash (Fraxinus excelsior L.) wood samples were obtained from a French wood company (Bois Durables de Bourgogne, 71120 Vendenesse-lès-Charolles, France). Twenty boards measuring 4000 x 110 x 25 $\left(\mathrm{mm}^{3}\right)(\mathrm{L} \times \mathrm{R} \times \mathrm{T})$ were selected. Special attention was paid to ensure these planks only had small variations in density (around $650 \mathrm{~kg} / \mathrm{m}^{3} \pm 10 \%$ ) and a uniform width of annual rings. All the planks were sawn into two equal parts of $2 \mathrm{~m}$ in length. Half of each plank was used as reference material and the other half was thermally treated at different treatment intensities. The planks were then dried at $103^{\circ} \mathrm{C}$ in an industrial oven up to mass stabilization $\left(\mathrm{m}_{0}\right)$.

\section{Heat treatment protocols}

The thermal treatment processes were carried out at the same company. These operations were carried out in a 20 cubic meter industrial oven $\left(\mathrm{Jartek}^{\circledR}\right)$, in convection heat-transfer mode and under a steam pressure process (ThermoWood $\mathbb{R}$ method, Finnish Thermowood Association (2003)).

The temperatures of the wood core and that of the oven atmosphere were dynamically recorded and monitored throughout the treatment (Figure 1), in order to optimize the process and the final wood qualities.

The oven temperature was firstly increased rapidly $\left(0,5^{\circ} \mathrm{C} / \mathrm{min}\right)$ to $100{ }^{\circ} \mathrm{C}$, then slowly $\left(0,2{ }^{\circ} \mathrm{C} / \mathrm{min}\right)$ to 150 ${ }^{\circ} \mathrm{C}$. This temperature level was maintained for $1 \mathrm{~h}$. The temperature was finally increased $\left(0,2{ }^{\circ} \mathrm{C} / \mathrm{min}\right)$ to the desired level (from a low temperature $\left(170{ }^{\circ} \mathrm{C}\right.$ to $\left.200{ }^{\circ} \mathrm{C}\right)$ to a high temperature $\left(215^{\circ} \mathrm{C}\right.$ to $228{ }^{\circ} \mathrm{C}$ ) and kept at that constant level for 2 hours. Steam was injected into the chamber to keep it oxygen-free and to influence chemical changes in the wood. The heating system was then stopped and the wood samples were cooled to room temperature in an oxygen-free atmosphere with a water spray.

Each heat treatment was carried out simultaneously on four ash wood planks. 


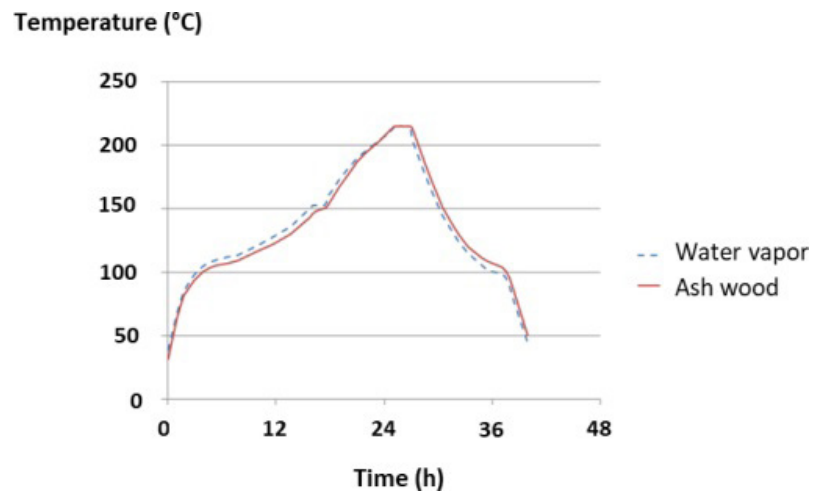

Figure 1: Temperature kinetics of ash wood and water vapor during heat treatment carried out at $215^{\circ} \mathrm{C}$ for 2 hours.

\section{Mass Loss (ML) due to wood thermal degradation}

Each raw ash wood plank measuring $2000 \times 110 \times 25\left(\mathrm{~mm}^{3}\right)(\mathrm{L} \times \mathrm{R} \times \mathrm{T})$ was dried at $103{ }^{\circ} \mathrm{C}$ up to mass stabilization and its anhydrous mass was measured $\left(\mathrm{m}_{0}\right)$. After a thermal modification process each treated ash wood plank was again dried at $103{ }^{\circ} \mathrm{C}$ and its anhydrous mass was re-measured $\left(\mathrm{m}_{1}\right)$. The Mass Loss (ML\%) due to wood thermal degradation depending on treatment conditions was determined by the following Equation 1.

$$
\operatorname{ML}(\%)=\left[\frac{\left(m_{0}-m_{1}\right)}{m_{0}}\right] x 100
$$

\section{Biological resistance tests on wood block samples}

\section{Decay resistance}

Decay and termite resistance tests were carried out according to adaptations of XP CEN/TS 15083-1 (CEN 2006) and EN 117 (CEN 2012) standard criteria, respectively, in one of our previous studies (Candelier et al. 2017). The protocols used for these durability tests are detailed in that previous work.

\section{Extraction protocols}

All the experimental procedures used to determine extractive contents were adapted, with minor modifications, from procedures found in the scientific literature (Rowell et al. 2005).

A mix of several pieces (One 20-cm long piece, per wood board) from untreated and heat-treated planks was crushed and sieved to obtain particle sizes from to 0,2 and $0,5 \mathrm{~mm}$, for each temperature level. After a drying step at $103^{\circ} \mathrm{C}$ up to mass stabilization $\left(\mathrm{m}_{2}\right)$, the sawdusts $(10 \mathrm{~g})$ were separately extracted in a Soxhlet with acetone (Sigma Aldrich, 32201-M) (6 h), or with hot water $(2 \times 6 \mathrm{~h})$, and dried at $103^{\circ} \mathrm{C}$ for $48 \mathrm{~h}$ to obtain the anhydrous mass $\left(\mathrm{m}_{3}\right)$.

For untreated and heat-treated ash wood under varying temperature conditions, extractive contents were determined by the following Equation 2.

$$
\operatorname{Ext}(\%)=\left[\frac{\left(m_{2}-m_{3}\right)}{m_{2}}\right] \times 100
$$




\section{Antifungal activity test}

Antifungal activities against the growth of Trametes versicolor Quélet (TV) (Linnaeus, CTB 863 A) and Rhodonia placenta Coocke sensu J. Erikson (PP) (Fries, FPRL 280) were tested as per Salem et al. (2014) with some variations.

Each Petri dish ( $9 \mathrm{~cm}$ diameter) was filled with $10 \mathrm{~mL}$ of malt-agar medium containing $1200 \mu \mathrm{L}$ of the diluted extracts in water or acetone (Merck company, Darmstadt, Germany) $(\mathrm{C}=2,5 \% \mathrm{~m} / \mathrm{m})$ and left to solidify. These dilutions were chosen according to past studies (Esteves et al. 2011, Pal et al. 2011). A 1-cm square section of a seven-day-old culture of Rhodonia placenta or Trametes versicolor was placed in the center of the Petri dish and stored in a climatic chamber regulated at $22^{\circ} \mathrm{C} \pm 2{ }^{\circ} \mathrm{C}$ and $70 \% \pm 5 \%$ relative humidity $(\mathrm{RH})$ for seven days' incubation. Three replicates were carried out per diluted wood extract sample and per fungus. Three media free of extractives and without solvent were used as a control. In addition, three media free of extractives and with solvent (water or acetone alone) were used to check that the water and acetone solvents did not have any impact on the activity of each fungus. Following the fungal exposure period, the mycelium growth diameter was measured in millimeters, for the control medium $\left(\mathrm{M}_{\mathrm{c}}\right)$ and the extract-supplemented medium $\left(\mathrm{M}_{\mathrm{t}}\right)$. The percentage of mycelium growth inhibition was determined by Equation 3 .

$$
\text { Inhibition }(\%)=\left[\frac{\left(M_{c}-M_{t}\right)}{M_{c}}\right] \times 100
$$

\section{Anti-termite activity test}

The anti-termite activities of each heat-treated ash wood extract were tested by screening tests. Anhydrous cellulose paper measuring $2,5 \mathrm{~cm}$ in diameter was weighed $\left(\mathrm{m}_{4}\right)$ and then impregnated with $70 \mu \mathrm{L}$ of the diluted extracts in water or acetone $(\mathrm{C}=2,5 \% \mathrm{~m} / \mathrm{m})$, air dried $\left(20^{\circ} \mathrm{C} \pm 2{ }^{\circ} \mathrm{C}\right.$ and $\left.65 \% \pm 5 \%\right)$ for 2 hours $\left(\mathrm{m}_{4}\right)$, then placed in the center of a Petri dish $(5,5 \mathrm{~cm}$ diameter). Fifteen grams of wet sand (4 vol. sand $/ 1$ vol. water) was placed evenly around the paper and 20 termite workers (Reticulitermes flavipes, ex. santonensis) were added to each test set-up. Three replicates were carried out for each diluted wood extract. Three papers impregnated with water or acetone alone were tested to estimate the impact of the solvent on termite activity. Tests with water only were considered as a virulence control. For each test set-up, the paper samples were placed on a plastic grid. Lastly, three diet control set-ups containing only $15 \mathrm{~g}$ of wet sand and 20 termites were used to check termite survival without any feeding possibilities/without any trophic sources. All test set-ups were kept at $27^{\circ} \mathrm{C}$ and $>75 \%$ RH (Figure 2).

Every two days, each test set-up was observed to check sand humidity, add water if needed and keep track of termite behavior and activity. When all the termites contained in the diet control set-ups had died, the test was stopped. The termite survival rate was then determined, the anhydrous mass of the cellulose papers was measured $\left(\mathrm{m}_{5}\right)$ and the Weight Losses $\left(\mathrm{WL}_{\text {term. }}\right.$ \%) due to termite degradation were calculated by the following Equation 4.

$$
W L_{\text {term. }}(\%)=\left[\frac{\left(M_{4}-M_{5}\right)}{M_{4}}\right] \times 100
$$




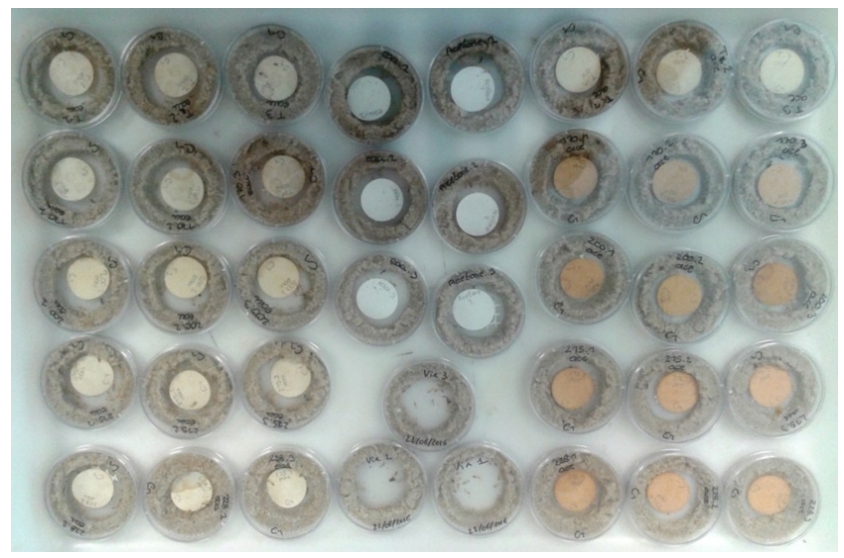

Figure 2: Termite screening test set-ups at the start of termite exposure.

\section{GC-MS analysis}

The wood extracts (acetone and water) were analyzed on a Perkin Elmer Clarus 680 Gas Chromatograph (GC) with a fused silica DB-5MS (diméthyl-/diphényl-polysiloxane, 95:5) column (30 m, 0,25 mm, 0,25 $\mu \mathrm{m}$ ), coupled with a Perkin Elmer Clarus SQ8 Mass Spectrometer (MS) and monitored by Turbo Mass v.6.1 software.

Before being injected into the GC-MS analyzer, the extractive substance samples were derivatized in order to improve the detection of all chemical compounds. To perform this silylation derivatization process, $2 \mathrm{mg}$ of extract was solubilized in a glass tube with $50 \mu \mathrm{L}$ of BSTFA $+1 \%$ TMCS solution (Bistrimethylsilyltrifluoroacetamide + Trimethylchlorosilane) (Acros Organics). The glass tube was sealed and dried in an oven at $70{ }^{\circ} \mathrm{C}$ for 120 minutes, then opened to evaporate the BSTFA. The derivatized wood extract was dissolved in $1 \mathrm{~mL}$ of $\mathrm{C}_{4} \mathrm{H}_{8} \mathrm{O}_{2}$ solution (ethyl acetate (Acros Organics)). One $\mu \mathrm{L}$ of this solution was injected into the Gas Chromatograph at a $250{ }^{\circ} \mathrm{C}$ inlet temperature in splitless mode. Helium was used as the carrier gas. The temperature program was: $80^{\circ} \mathrm{C}(2 \mathrm{~min}), 10^{\circ} \mathrm{C} / \mathrm{min}$ to $190{ }^{\circ} \mathrm{C} 15^{\circ} \mathrm{C} / \mathrm{min}^{-1}$ to $280{ }^{\circ} \mathrm{C}$ - maintained for 10 minutes, $10{ }^{\circ} \mathrm{C} / \mathrm{min}$ to $300{ }^{\circ} \mathrm{C} 15^{\circ} \mathrm{C} / \mathrm{min}^{-1}$ - maintained for 14 minutes. A helium flow of $1 \mathrm{~mL} / \mathrm{min}$ was used as the mobile phase. After this separation step, compounds were transferred to the Mass Spectrometer by a transfer line heated at $250{ }^{\circ} \mathrm{C}$ and ionization was achieved by the Electron Impact method ( $70 \mathrm{eV}$ ionization energy).

The recognition of each component was achieved by comparing its mass spectrum with the NIST Library 2005 using NIST MS Search 2.0 (2011) software. The identification was deemed to be relevant when the comparison coefficient was higher than 900 (The comparison coefficient corresponds to the match factor between the mass spectrum obtained by a GC-MS analysis and the mass spectrum from the NIST MS Search 2.0 (2011). The match factors ranged from 0 to 1000, with 0 meaning no match and 1000 meaning a total match).

\section{Determination of $\mathrm{pH}$ Value}

pH measurements were conducted according to Wang et al. (2012). Untreated and heat-treated samples were ground and passed through 40-60 mesh screens. Three grams of oven-dried sawdust samples was soaked in $30 \mathrm{~mL}$ of distilled water and then stirred for $5 \mathrm{~min}$, allowed to stand for $15 \mathrm{~min}$, stirred for another $5 \mathrm{~min}$, and then left to stand for another $20 \mathrm{~min}$. After this procedure, the $\mathrm{pH}$ values of the liquid were determined using a pH meter (PH/mVmeter Knick 911 ATEX; Knick Elektronische ${ }^{\mathrm{TM}}$, Berlin, Germany).

\section{Statistical analysis}

The impact of heat treatment intensity compared to the untreated ash wood on (i) the termite and fungal resistance of the wood samples, (ii) the content and (iii) the effects of water and acetone extractives on their antifungal and anti-termite efficiency were evaluated using an ANOVA (one-way analysis of variance) and Duncan's comparison test. These statistical analyses were carried out by the JMP 10.0.2 program (SAS 2012) by applying the Fisher test. The results were then ranked into several categories, from "a" to "e" for the water-extractives and from " $A$ " to " $E$ " for the acetone-extractives. The impact of a parameter on a system not connected by the same letter was considered as non-significant at the $5 \%$ level. 


\section{RESULTS AND DISCUSSION}

\section{Biological resistance tests on wood block samples}

Decay and termite resistance tests were previously undertaken in Candelier et al. (2017). In order to put into perspective, the biological durability of untreated and heat-treated solid wood with the following antifungal and anti-termite activities of the respective wood extractive fractions, this section focuses solely on the main results obtained by Candelier et al. (2017).

\section{Decay resistance}

Similar results were found for both of the rots tested. However, Rhodonia placenta was the most aggressive rot on beech control samples (WL 49,9\%), whereas Trametes versicolor was the most degrading rot on ash control samples (WL $48 \%$ ). Thermal modification increased the durability of all wood materials, which was in agreement with previous studies (Kamdem et al. 2002, Esteves and Pereira 2009). These results were expected as Rousset et al. (2004) and Metsä-Kortelainen et al. (2005) also found that the thermal treatment of wood at high temperatures increases the resistance of wood to decay.

According to Table 1, the thermal treatment carried out at temperatures over $200{ }^{\circ} \mathrm{C}$ conferred the "very durable" durability class 1 to the heat-treated wood materials, according to the classification method of XP CEN/TS 15083-1 (CEN 2006).

Table 1: Resistance of untreated and heat-treated ash wood block samples to Trametes versicolor and Rhodonia placenta fungi and to Reticulitermes flavipes termite species (taken from Candelier et al. (2017)).

\begin{tabular}{|c|c|c|c|c|c|c|c|}
\hline \multirow{3}{*}{$\begin{array}{l}\text { Wood } \\
\text { species }\end{array}$} & \multirow{3}{*}{$\begin{array}{l}\text { Temperature } \\
\text { of thermal } \\
\text { modification } \\
\text { process } \\
\left({ }^{\circ} \mathrm{C}\right)\end{array}$} & \multicolumn{3}{|c|}{ Decay resistance } & \multicolumn{3}{|c|}{ Termite resistance (Reticulitermes flavipes) } \\
\hline & & $\begin{array}{l}\text { Trametes } \\
\text { versicolor }\end{array}$ & $\begin{array}{c}\text { Rhodonia } \\
\text { placenta }\end{array}$ & \multirow{2}{*}{$\begin{array}{l}\text { Durability } \\
\text { class }\end{array}$} & \multirow{2}{*}{ ML (\%) } & \multirow{2}{*}{ Survival rate (\%) } & \multirow{2}{*}{ Visual rating * } \\
\hline & & WL $(\%)$ & WL $(\%)$ & & & & \\
\hline Beech & Control & $23,0(0,13) \mathrm{a}$ & $49,9(0,11) \mathrm{a}$ & 5 & $8,87(1,98) \mathrm{abc}$ & $69,50(13,10) \mathrm{ab}$ & 4 \\
\hline Pine & Control & n.c & n.c & n.c & $11,12(1,57) \mathrm{a}$ & $64,50(9,43) \mathrm{bc}$ & 4 \\
\hline \multirow{5}{*}{ Ash } & Control & $48,0(0,10) \mathrm{b}$ & $39,7(0,09) \mathrm{ab}$ & 5 & $4,58(0,57) \mathrm{d}$ & $69,67(8,33) \mathrm{ab}$ & 4 \\
\hline & 170 & $5,02(0,05) \mathrm{c}$ & $6,2(0,12) \mathrm{c}$ & 2 & $11,80(2,60) \mathrm{a}$ & $78,67(4,16) \mathrm{a}$ & 4 \\
\hline & 200 & $2,8(0,13) \mathrm{d}$ & $2,2(0,09) \mathrm{d}$ & 1 & $11,60(2,12) \mathrm{a}$ & $71,33(6,11) \mathrm{ab}$ & 4 \\
\hline & 215 & $1,5(0,19) \mathrm{e}$ & $0,9(0,07) \mathrm{e}$ & 1 & $10,86(1,51) \mathrm{a}$ & $56,67(5,03) \mathrm{bcd}$ & 4 \\
\hline & 228 & $1,1(0,10) \mathrm{f}$ & $0,7(0,05) \mathrm{e}$ & 1 & $9,23(1,97) \mathrm{ab}$ & $51,33(13,61)$ bed & $4(67 \%) ; 3(33 \%)$ \\
\hline
\end{tabular}

WL\% - Median values

ML\% - Average values

Values within each column and factor followed by the same letter are not significantly different.

* " 0 " for no attack " 1 " for attempted attack, " 2 " for slight attack, " 3 " for average attack, " 4 " for a strong attack.

** According to a one-way analysis of variance, systems not connected by the same letter are largely different at the $5 \%$ level.

\section{Termite resistance}

Termite survival revealed an effect on termite biology. Although the survival rate was similar for treatments at $170{ }^{\circ} \mathrm{C}$ and $200{ }^{\circ} \mathrm{C}$, it was lower above those temperatures (Table 1). Heat treatments at temperatures over $200{ }^{\circ} \mathrm{C}$ caused critical changes to the wood and consequently its durability could be improved. As the wood was nonetheless degraded, the toxicity of the components consumed may explain the higher termite mortality rate (Surini et al. 2012) depending on the increase in heat treatment intensity. However, it was not particularly effective over a short time scale, as $51,33 \%$ of the termites were still alive after the test, with no significant differences between treated and untreated wood. The current results are in agreement with those of Nunes et al. (2004), who studied the resistance to termites of the species Reticulitermes grassei with wood treated by the German method (OHT) and concluded that, in spite of the slightly higher mortality of termites in treated samples and a smaller weight loss, the differences were not significant.

\section{Extractive content}


For thermal treatment carried out at a low temperature $\left(<215^{\circ} \mathrm{C}\right)$, the proportions of heattreated wood extractives increased in comparison with those of untreated ash wood, whatever the solvent used during the extraction process (Figure 3). This result tallied with past studies, indicating an increase in extractive rate resulting from the generation of different degradation products (Poncsak et al. 2009, Esteves et al. 2008). A past study by Esteves et al. (2008), carried out on eucalypt wood, showed that thermal degradation of lignin and hemicelluloses led to an increase in extractive content. In fact, the formation of new extractive compounds arising from polysaccharide degradation at around $160^{\circ} \mathrm{C}$ may be one of the reasons for that phenomenon. At higher temperatures $\left(>215^{\circ} \mathrm{C}\right)$, these new compounds are also generated but, under the heat effect, they are then converted into volatile products that leave the structure of the wood, thus causing a loss of matter, leading to a decrease in extractive content (Wang et al. 2016).

The relative percentage contents of extractives (Figure 3) increased at low treatment temperatures, reaching maximum values of $4,59 \%$ and $2,19 \%$ for thermal treatment carried out at $170^{\circ} \mathrm{C}$ and for water and acetone extractions, respectively. Beyond that temperature the relative extractive percentage decreased.

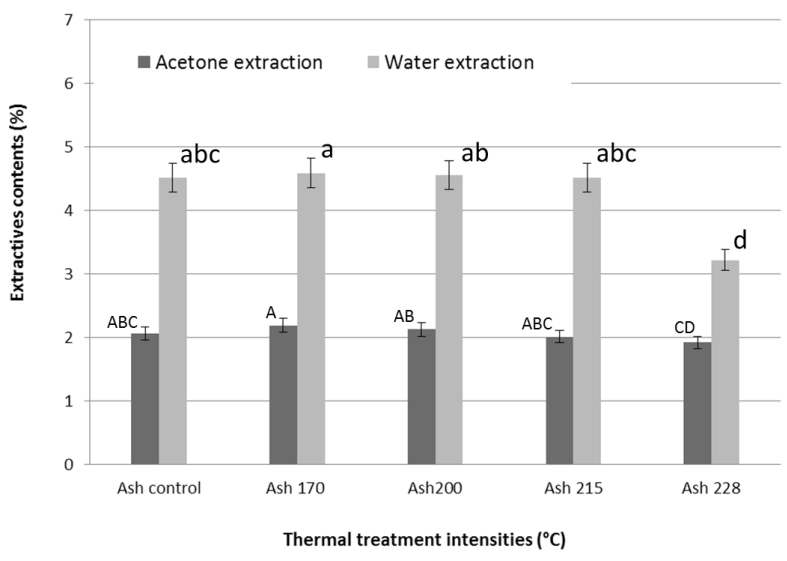

Figure 3: Extractive contents (\%) of untreated and heat-treated ash woods at different temperature levels $\left(170^{\circ} \mathrm{C}\right.$ to $228^{\circ} \mathrm{C}$ ), depending on the extraction solvent used (bar followed by a same letter are not significantly different).

\section{Antifungal activity test}

Fungal activity was inhibited by the heat-treated and untreated ash wood extracts. Table 2 and Figure 4 shows how fungal development was hindered depending on the extractive compounds. However, for both of the fungus species tested, the effectiveness of the extracts varied depending on the heat treatment temperature and the solvent used during the extraction process. It clearly appeared that untreated and heat-treated ash wood extracts were more efficient against brown-rot (Rhodonia placenta) than against white-rot (Trametes versicolor) growth, whatever the extraction solvent used. In both cases, the efficiency of the extracts seemed to be correlated to the heat treatment temperature.

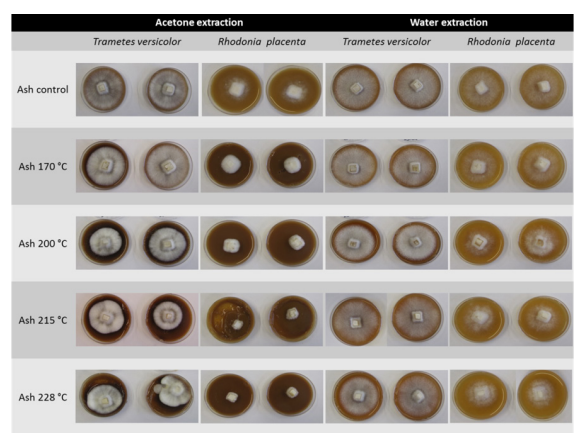

Figure 4: Trametes versicolor and Rhodonia placenta growth depending on the inhibition of untreated and heat-treated ash wood extracts $(1200 \mu \mathrm{L})$, after seven days. 
Table 2 indicates that heat-treated ash wood extracts were more efficient against Trametes versicolor and Rhodonia placenta after 3,5 days than after 7 days, except for the modified ash wood extracts extracted with acetone against Rhodonia placenta. It turned out that, 7 days after fungal exposure, acetone-extracts from ash wood modified at a temperature of $228^{\circ} \mathbf{C}$ delayed the growth of Trametes versicolor and Rhodonia placenta most.

Table 2: Effectiveness of untreated and heat-treated ash wood extracts $(1200 \mu \mathrm{L})$ against Trametes versicolor and Rhodonia placenta.

\begin{tabular}{|c|c|c|c|c|c|c|c|c|c|}
\hline \multirow[b]{3}{*}{$\begin{array}{c}\text { Extraction } \\
\text { method }\end{array}$} & \multirow{3}{*}{$\begin{array}{c}\text { Ash wood } \\
\begin{array}{c}\text { Thermal } \\
\text { treatment } \\
\text { temperature }\end{array}\end{array}$} & \multicolumn{4}{|c|}{ Trametes versicolor } & \multicolumn{4}{|c|}{ Rhodonia placenta } \\
\hline & & \multicolumn{2}{|c|}{3,5 days } & \multicolumn{2}{|c|}{7 days } & \multicolumn{2}{|c|}{3,5 days } & \multicolumn{2}{|c|}{7 days } \\
\hline & & $\begin{array}{c}\text { Inhibition } \\
(\%)\end{array}$ & $\begin{array}{c}\text { Standard } \\
\text { deviation } \\
(\%)\end{array}$ & $\begin{array}{c}\text { Inhibition } \\
(\%)\end{array}$ & $\begin{array}{c}\text { Standard } \\
\text { deviation } \\
(\%)\end{array}$ & $\begin{array}{c}\text { Inhibition } \\
(\%)\end{array}$ & $\begin{array}{c}\text { Standard } \\
\text { deviation } \\
(\%)\end{array}$ & $\begin{array}{c}\text { Inhibition } \\
(\%)\end{array}$ & $\begin{array}{c}\text { Standard } \\
\text { deviation } \\
\text { (\%) }\end{array}$ \\
\hline \multirow{5}{*}{ Acetone } & 0 & $24,01^{\mathrm{D}}$ & 1,40 & $31,49^{\mathrm{C}}$ & 1,02 & $42,05^{\mathrm{D}}$ & 0,00 & $44,90^{\mathrm{E}}$ & 0,00 \\
\hline & 170 & $37,83^{\mathrm{BC}}$ & 6,98 & $32,93^{\mathrm{BC}}$ & 5,10 & $50,57^{\mathrm{C}}$ & 2,41 & $61,22^{\mathrm{D}}$ & 2,89 \\
\hline & 200 & $44,74^{\mathrm{B}}$ & 2,79 & $42,31^{\mathrm{B}}$ & 2,04 & $42,05^{\mathrm{CD}}$ & 9,64 & $68,37^{\mathrm{C}}$ & 1,44 \\
\hline & 215 & $48,68^{\mathrm{AB}}$ & 8,37 & $46,63^{\mathrm{AB}}$ & 8,37 & $60,80^{\mathrm{AB}}$ & 2,41 & $76,53^{\mathrm{AB}}$ & 1,44 \\
\hline & 228 & $59,54^{\mathrm{A}}$ & 6,98 & $51,68^{\mathrm{A}}$ & 7,14 & $64,20^{A}$ & 2,41 & $79,63^{\mathrm{A}}$ & 1,44 \\
\hline \multirow{5}{*}{ water } & 0 & $14,14^{\mathrm{e}}$ & 1,40 & $31,49^{\mathrm{c}}$ & 1,02 & $47,16^{\mathrm{a}}$ & 2,41 & $14,29^{\mathrm{d}}$ & 2,89 \\
\hline & 170 & $20,07^{\mathrm{d}}$ & 1,40 & $32,21^{\mathrm{abc}}$ & 6,12 & $42,05^{\mathrm{b}}$ & 0,00 & $24,49^{\mathrm{bc}}$ & 2,89 \\
\hline & 200 & $38,82^{\text {bc }}$ & 2,79 & $35,82^{b}$ & 1,02 & $45,45^{\mathrm{a}}$ & 0,00 & $32,65^{\mathrm{a}}$ & 5,77 \\
\hline & 215 & $35,86^{\mathrm{ab}}$ & 1,40 & $36,54^{\mathrm{ab}}$ & 0,00 & $48,86^{\mathrm{a}}$ & 0,00 & $35,71^{\text {ab }}$ & 1,44 \\
\hline & 228 & $41,78^{\mathrm{a}}$ & 1,40 & $40,14^{\mathrm{a}}$ & 3,06 & $43,75^{\text {ab }}$ & 2,41 & $37,76^{\mathrm{a}}$ & 1,44 \\
\hline Water cont. & 1 & 0 & 1 & 0 & 1 & 0 & 1 & 0 & 1 \\
\hline Acetone cont. & 1 & 0 & 1 & 0 & 1 & 0 & I & 0 & 1 \\
\hline
\end{tabular}

Values within each column and factor followed by the same letter are not significantly different (letters from A to E were used to compare acetone-extractives and letters form a to e were used to compare water-extractives).

The different degrees of fungal development for untreated and thermally modified wood reflecting the contrasts in extractive chemical composition are displayed in Figure 6 and Figure 7. Although some effects of water and acetone extracts from heat-treated ash could be seen on fungal growth depending on the treatment intensity, this phenomenon was not significant. It appeared that the fungi adapted themselves to the new medium and regained normal growth after a few days of incubation. In other words, heat-treated wood extracts seem to have shortterm fungistatic action.

\section{Anti-termite activity test}

Table 3 and Figure 5 show that the heat-treated ash extract yields and their anti-termite activities were largely linked to the polar or nonpolar nature of the solvent used during the extraction process. In fact, anti-termite compounds can have many varied chemical characteristics and different polarity levels, which may or may not be soluble in a specific solvent (Kadir et al. 2015).

The test was stopped after 21 days, when the termites in the diet control set-ups had died. The results in Table 2 show that the anti-termite activity of the heat-treated ash wood extracts was not significant.

Table 3: Effectiveness of untreated and heat-treated ash wood extracts $(1200 \mu \mathrm{L})$ against Reticulitermes flavipes.

\begin{tabular}{|c|c|c|c|c|c|}
\hline \multirow[b]{2}{*}{$\begin{array}{c}\text { Extraction } \\
\text { solvent }\end{array}$} & Ash wood & \multirow[b]{2}{*}{$\begin{array}{l}\text { Weight loss } \\
(\%)\end{array}$} & \multirow[b]{2}{*}{$\begin{array}{c}\text { Standard } \\
\text { deviation } \\
(\%)\end{array}$} & \multirow[b]{2}{*}{$\begin{array}{l}\text { Survival rate } \\
(\%)\end{array}$} & \multirow[b]{2}{*}{$\begin{array}{l}\text { Standard } \\
\text { deviation } \\
(\%)\end{array}$} \\
\hline & $\begin{array}{c}\text { Thermal } \\
\text { treatment } \\
\text { temperature } \\
\left({ }^{\circ} \mathrm{C}\right)\end{array}$ & & & & \\
\hline \multirow{5}{*}{$\begin{array}{c}\text { Acetone } \\
\mathrm{C}=2,5 \% \\
(\mathrm{~m} / \mathrm{m})\end{array}$} & 0 & $45,25^{A}$ & 9,31 & $85,00^{A}$ & 5,00 \\
\hline & 170 & $34,86^{\mathrm{AB}}$ & 1,52 & $86,67^{A}$ & 7,43 \\
\hline & 200 & $34,49^{\mathrm{AB}}$ & 4,39 & $81,67^{\mathrm{AB}}$ & 2,89 \\
\hline & 215 & $32,17^{\mathrm{AB}}$ & 4,02 & $76,67^{\mathrm{ABC}}$ & 5,77 \\
\hline & 228 & $31,26^{\mathrm{B}}$ & 1,84 & $86,67^{\mathrm{A}}$ & 2,89 \\
\hline \multirow{5}{*}{$\begin{array}{c}\text { Water } \\
C=2,5 \% \\
(\mathrm{~m} / \mathrm{m})\end{array}$} & 0 & $54,62^{a b c}$ & 6,78 & $90,00^{\mathrm{a}}$ & 5,00 \\
\hline & 170 & $51,57^{\mathrm{c}}$ & 3,48 & $73,33^{\mathrm{cd}}$ & 2,89 \\
\hline & 200 & $53,25^{\mathrm{c}}$ & 3,36 & $80,00^{c}$ & 0,00 \\
\hline & 215 & $59,55^{\mathrm{ab}}$ & 2,52 & $76,67^{\mathrm{bc}}$ & 5,77 \\
\hline & 228 & $61,12^{a}$ & 3,05 & $90,00^{a}$ & 5,00 \\
\hline \multirow{2}{*}{ Control } & Acetone & $32,77^{\mathrm{AB} / \mathrm{d}}$ & 6,63 & $86,67^{\mathrm{A} / \mathrm{ab}}$ & 2,89 \\
\hline & Water & $31,98^{\mathrm{ABC} / \mathrm{d}}$ & 6,29 & $88,33^{\mathrm{A} / \mathrm{ab}}$ & 5,77 \\
\hline
\end{tabular}

Values within each column and factor followed by the same letter are not significantly different (letters from A to C were used to compare acetone-extractives and letters form a to e were used to compare water-extractives).

For untreated and treated ash wood under different treatment intensities, the mass loss due to termite deg- 
radation indicated that the relative extracts obtained with water were statistically more attractive for termites and the termite survival rate was quite similar to that of the control sample. This effect was related to the final temperature level of the thermal treatment. On the other hand, the same extractives obtained with acetone seemed to have no significant effect on termites compared to the water control samples (Figure 5).

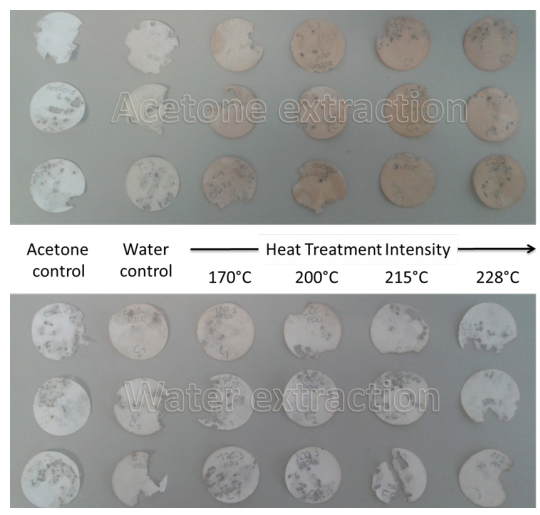

Figure 5: Effectiveness of untreated and heat-treated ash wood extracts $(1200 \mu \mathrm{L})$ against Reticulitermes flavipes.

The termite survival rate revealed no significant effect on the biology of these insects. The survival rate was not significantly dissimilar for the different treatments compared to the control samples. The effects of untreated wood extracts on the termite survival rate were very similar to those for heat-treated wood, confirming the innocuous property of these treated wood extracts in terms of termite toxicity.

\section{GC-MS analysis}

\section{Water extractives}

The typical chromatograms from GC-MS analyses of the chemical composition of untreated and thermally modified ash wood extracts by the water extraction process are presented in Figure 6.

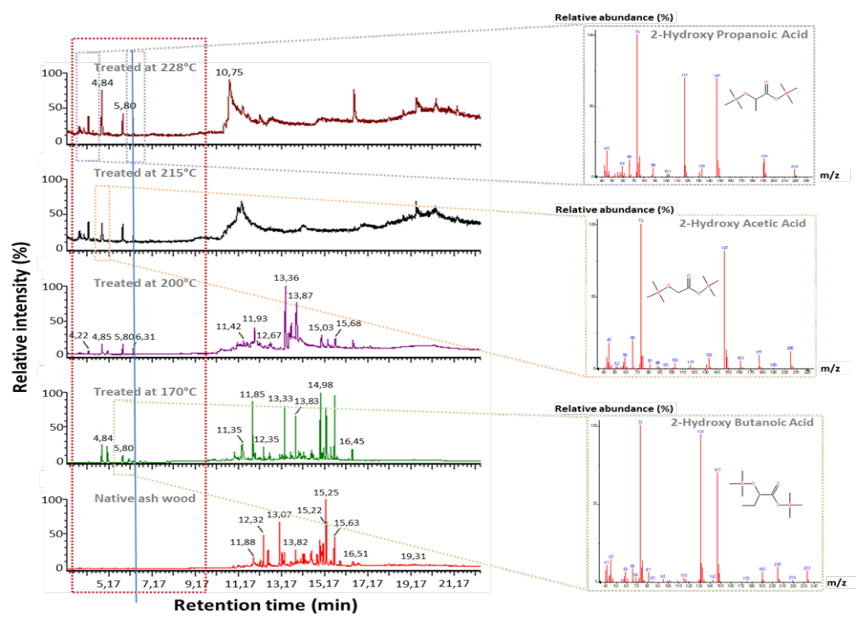

Figure 6: Untreated and heat-treated ash wood water-extractive composition identified by GC-MS, depending on the thermal treatment temperature.

For untreated ash wood, the GC-MS analysis highlighted that almost all of the original water extractives 
resulted from polysaccharides or their silylated fragments. Only the weak peak observed at $\mathrm{rt}=11,88 \mathrm{~min}$ corresponded to the antioxidant Tyrosol (4-hydroxyphenylethanol).

For the ash wood treated at $170^{\circ} \mathrm{C}$, it was found that the respective water extracts mainly comprised low molecular weight organic 2-hydroxy-acids (propanoic acid ( $\mathrm{rt}=4,84 \mathrm{~min}$ and 6,09 min), acetic acid ( $\mathrm{rt}=5,10$ $\mathrm{min}$ ), butanoic acid $(\mathrm{rt}=5,80 \mathrm{~min})$ ) (Table 5) and derivated phenylpropanoid compounds $(\mathrm{rt}=11,00 \mathrm{~min}$ and $11,35 \mathrm{~min}$ ). The presence of these acid compounds, decreasing the $\mathrm{pH}$ of the wood, may have played a role in fungal inhibition. Indeed, according to the results presented in Table 4, the $\mathrm{pH}$ values of ash wood decreased depending on the temperature used during the heat treatment process. The $\mathrm{pH}$ values varied from 5,16 for untreated wood to 3,92 for wood thermally modified at $228^{\circ} \mathbf{C}$. Similar trends were observed on softwood and hardwood species by Niemz et al. (2010), showing that the $\mathrm{pH}$ decreases with increasing heat treatment intensity.

Table 4: $\mathrm{pH}$ values of untreated and heat-treated ash wood.

\begin{tabular}{|c|c|c|}
\hline \multirow{2}{*}{ Wood species } & $\begin{array}{c}\text { Thermal treatment } \\
\text { temperature }\left({ }^{\circ} \mathrm{C}\right)\end{array}$ & $\mathbf{p H}$ \\
\hline \multirow{4}{*}{ Ash wood } & 0 & $5,16(0,15)^{\mathrm{a}}$ \\
\cline { 2 - 3 } & 170 & $4,51(0,16)^{\mathrm{b}}$ \\
\cline { 2 - 3 } & 200 & $4,12(0,17)^{\mathrm{c}}$ \\
\cline { 2 - 3 } & 215 & $4,03(0,16)^{\mathrm{dd}}$ \\
\cline { 2 - 3 } & 228 & $3,92(0,14)^{\mathrm{cde}}$ \\
\hline
\end{tabular}

Values followed by the same letter are not significantly different.

Indeed, Yalcin and Sahin (2015) reported that heat treatment conferred on narrow-leaved ash wood a $\mathrm{pH}$ that was less conducive to fungal growth, with the untreated wood $\mathrm{pH}$ of 5,7 falling to 3,9 in the modified wood, while the $\mathrm{pH}$ for optimum fungal growth is around 5-6 (Bozkurt et al. 1993). In addition, such a decrease in wood $\mathrm{pH}$ could disturb the enzymatic digestion of termites during their wood destruction (Lima et al. 2014). In fact, $\mathrm{pH}$ widely affects the activity of fungal enzymes. The $\mathrm{pH}$ dependence is usually due to the side groups of the amino acids. A diminution in $\mathrm{pH}$ changes the protonation pattern resulting in protein denaturation (in shape, charge and location within the substrate) (Purich 2010).

For ash woods treated at higher temperatures, from $200{ }^{\circ} \mathrm{C}$ to $228^{\circ} \mathrm{C}$, only traces of the previously mentioned low molecular weight organic acids were observed. In addition, a large peak located in the polysaccharide area, from $\mathrm{rt}=10 \mathrm{~min}$ and $\mathrm{rt}=13 \mathrm{~min}$, was observed but remained unidentified. These last peaks may have been due to the condensation of several chemical compounds produced by wood thermal degradation and might also partially explain the greater fungal resistance of wood thermally treated at high temperatures (Hakkou et al. 2006).

\section{Acetone extractives}

The typical chromatograms from GC-MS analyses for the chemical composition of untreated and thermally modified ash wood extracts by the acetone extraction process are presented in Figure 7. 


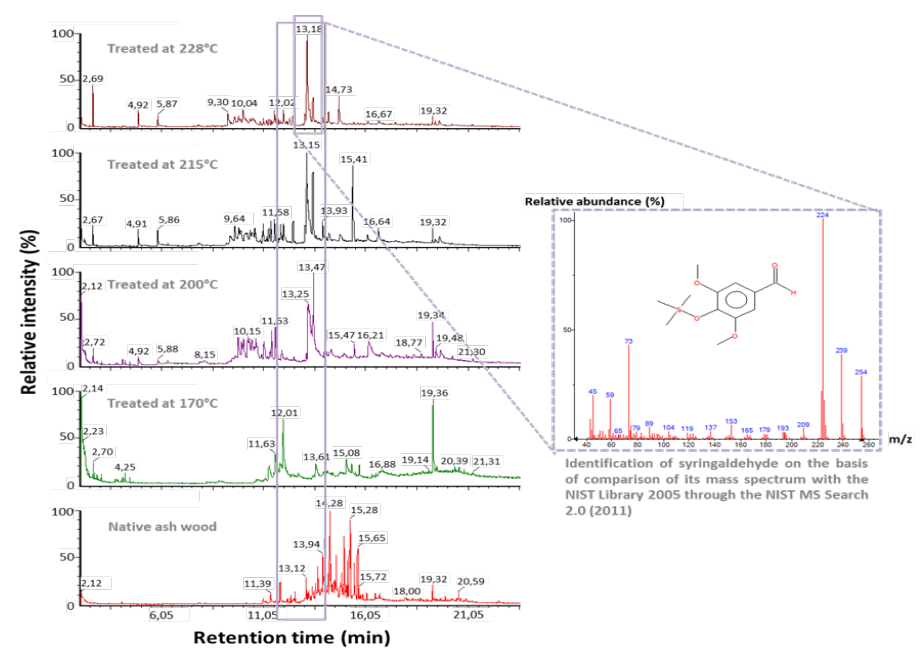

Figure 7: Untreated and heat-treated ash wood acetone-extractive composition identified by GC-MS, depending on the thermal treatment temperature.

The GC-MS analysis revealed that almost all of the untreated acetone-extractives disappeared after heat treatment, but on the other hand the thermal degradation of hemicelluloses and lignin generated new compounds. Monosaccharides and some products derived from their dehydration reactions, along with syringaldehyde (13,18 min, Figure 7), were the most abundant products generated by the heat treatment. Syringaldehyde appeared to be the product formed in the largest amounts, arising from lignin degradation, and was generally the major detected component according to the TIC chromatograms, Table 5.

Table 5: Retention time and Peak Intensities from GC-MS analyses of untreated and heat-treated ash wood extracts.

\begin{tabular}{|c|c|c|c|c|c|c|c|c|c|c|c|}
\hline \multirow{2}{*}{$\begin{array}{l}\text { Wood } \\
\text { species }\end{array}$} & \multirow{2}{*}{$\begin{array}{c}\text { Thermal } \\
\text { treatment } \\
\text { temperature } \\
\left({ }^{\circ} \mathrm{C}\right)\end{array}$} & \multicolumn{4}{|c|}{ Propanoic acid } & \multicolumn{2}{|c|}{ Acetic acid } & \multicolumn{2}{|c|}{ Butanoic acid } & \multicolumn{2}{|c|}{ Syringaldehyde } \\
\hline & & $\begin{array}{l}\mathbf{R t}^{*} \text { * } \\
\text { (min) }\end{array}$ & $\begin{array}{c}\text { Intensity }{ }^{* *} \\
(\%)\end{array}$ & $\underset{(\mathrm{min})}{\mathbf{R t}}$ & $\begin{array}{c}\text { Intensity } \\
(\%)^{*}\end{array}$ & $\begin{array}{c}\mathbf{R t} \\
\text { (min) }\end{array}$ & $\begin{array}{c}\text { Intensity } \\
(\%)\end{array}$ & $\begin{array}{c}\mathrm{Rt} \\
(\mathbf{m i n})\end{array}$ & $\begin{array}{c}\text { Intensity } \\
(\%)\end{array}$ & $\underset{(\min )}{\mathbf{R t}}$ & $\begin{array}{c}\text { Intensity } \\
(\%)\end{array}$ \\
\hline \multirow{5}{*}{ Ash } & Control & 4,21 & 1 & 6,31 & 1 & 4,84 & 5 & 5,8 & 2 & 13,12 & 28 \\
\hline & 170 & 4,21 & 3 & 6,31 & 4 & 4,84 & 22 & 5,8 & 6 & 13,11 & 12 \\
\hline & 200 & 4,22 & 9 & 6,31 & 12 & 4,85 & 18 & 5,8 & 19 & 13,25 & 67 \\
\hline & 215 & 4,23 & 37 & 6,31 & 21 & 4,85 & 39 & 5,8 & 38 & 13,15 & 100 \\
\hline & 228 & 4,23 & 39 & 6,32 & 37 & 4,84 & 78 & 5,8 & 41 & 13,18 & 100 \\
\hline
\end{tabular}

* $\mathrm{Rt}=$ Retention time (in minutes) shows the time taken for the analytes to pass through the column and reach the mass spectrometer detector. **Intensity (as a \%) represents a reflection of the amount of a specific analyte that was present, compared to the predominant one (e.g. Intensity $=100 \%)$.

Similar results for syringaldehyde extraction, by water and ethanol, from heat-treated wood were found by Ibrahim et al. (2012). The syringaldehyde content increased depending on the thermal treatment intensity, more particularly for wood treated at temperatures over $200{ }^{\circ} \mathrm{C}$ (Figure 7), and might explain the fungal inhibition activities of the heat-treated wood extractives. Indeed, previous studies highlighted the antifungal and anti-microbial activities of the phenolic compound syringaldehyde. Murugesan et al. (2009) also showed that syringaldehyde inhibited the growth of bacteria and of the fungus Ganoderma lucidum in syringaldehyde-treated malachite green samples. De Souza et al. (2005) also reported that syringaldehyde expounded anti-fungal activity against Leucoagaricus gongylophorus. According to Ibrahim et al. (2012), syringaldehyde (also called 3,5-dimethoxy-4-hydroxybenzaldehyde), has the same kind of structure as vanillin and is a unique natural compound that has bioactive properties (antioxidant, antifungal, anti-microbial and anti-tumorigene- 
sis), which belongs to the phenolic aldehyde family. In a past study, syringaldehyde displayed a successful role in inhibiting fungal growth rates (Kelly et al. 2008). Its fungicidal effects were mainly due to aldehyde moiety and the hydroxyl substituent

present in syringaldehyde (De Souza et al. 2005). Total hydroxyl groups from lignin also had a large impact on cellulase adsorption and enzymatic hydrolysis occurring during fungal degradation (Yu et al. 2014), and more particularly acetosyringone, vanillin and syringaldehyde (Qin et al. 2016). Ximenes et al. (2011) confirmed that syringaldehyde and vanillin inhibit cellulose hydrolysis. Although syringaldehyde displayed insecticidal properties against Acanthoscelides obectus beetles in a past study (Regnault-Roger et al. 2003), the concentrations tested in this work did not make it possible to confirm its insecticidal behavior on termite activity.

\section{CONCLUSIONS}

Heat treatment improved wood durability, clearly increasing resistance to brown and white rots, but it had only a slight effect in improving resistance to termites. The process carried out at $228{ }^{\circ} \mathbf{C}$ was found to give ash wood the best biological resistance properties. However, it can be expected that such treatment will greatly degrade the mechanical properties of the wood.

In addition, the results presented in this work confirmed that thermal treatment generates new extractive substances within the modified wood material, depending on the treatment temperature level, which could act as fungistatics and prevent fungus from growing, improving the resistance of the modified wood to decay. The antifungal activity of heat-treated ash wood extracts varied depending on heat treatment intensity and the solvent used during the extraction process, but these effects were not efficient over the long term and were not significant. It also clearly appeared that extracts from heat-treated ash wood were more efficient against brownrot growth than against white-rot growth. The analysis of these extractive compounds showed that the most abundant was syringaldehyde. In addition, the syringaldehyde content increased in line with the thermal treatment intensity, whatever the extraction process used. Although syringaldehyde has shown insecticidal properties in past studies, it could not be shown in our study that it has an insecticidal role against termites. The generation of low molecular weight organic acids might decrease the $\mathrm{pH}$ of wood, also impacting fungal inhibition and the enzymatic digestive system of termites. Lastly, the condensation of several chemical compounds from wood thermal degradation might also partially explain the better decay resistance of wood treated at high temperature. However, taken separately, the extractive compounds might act differently from the same extracts present within the wood. The increased durability of heat-treated ash wood is due to thermal degradation of wood cell wall polymers involving a combination of modifications: hydrophobic behavior, lignin modification, hemicellulose degradation and also extractive generation. To conclude, the results obtained in this study showed that the extractive compounds of heat-treated wood have a slight impact on the better durability of thermally modified wood, but are certainly not the only reason.

\section{REFERENCES}

Altgen, M.; Kyyrö, S.; Paajanen, O.; Rautkari, L. 2019. Resistance of thermally modified and pressurized hot water extracted Scots pine sapwood against decay by the brown-rot fungus Rhodonia placenta. Eur $J$ Wood Prod 78(1): 161-171. https://doi.org/10.1007/s00107-019-01482-z.

Boonstra, M.J.; Van Acker, J.; Tjeerdsma, B.F.; Kegel, E.V. 2008. Strength properties of thermally modified softwoods and its relationto polymeric structural wood constituents. Ann For Sci 64: 679-690. http:// dx.doi.org/10.1051/forest:2007048.

Bozkurt, A.Y.; Göker, Y.; Erdin, N. 1993. Emprenye Tekniği. İstanbul Üniversitesi Orman Fakültesi 
Yayınlar1, 3779/425.

Calonego, F.W.; Severo, E.T.D.; Furtado, E.L. 2010. Decay resistance of thermally-modified Eucalyptus grandis wood at $140{ }^{\circ} \mathrm{C}, 160{ }^{\circ} \mathrm{C}, 180{ }^{\circ} \mathrm{C}, 200{ }^{\circ} \mathrm{C}$ and $220^{\circ} \mathrm{C}$. Bioresour Technol 101(23): 9391-9394 https://doi.org/10.1016/j.biortech.2010.06.119.

Candelier, K.; Thévenon, M.F.; Pétrissans, A.; Dumarcay, S.; Gérardin, P.; Pétrissans, M. 2016. Control of wood thermal treatment and its effects on decay resistance: a review. Ann For Sci 73(3): 571-583. https://doi.org/10.1007/s13595-016-0541-X.

Candelier, K.; Hannouz, S.; Thévenon, M.F.; Guibal, D.; Gérardin, P.; Pétrissans, M.; Collet, R. 2017. Resistance of thermally modified ash (Fraxinus excelsior L.) wood under steam pressure against rot fungi, soil-inhabiting micro-organisms and termites. Eur J Wood Prod 75(2): 249-262. https://doi.org/10.1007/ s00107-016-1126-y.

CEN. 2006. Durability of wood and wood-based products - Determination of the natural durability of solid wood against wood destroying fungi - Test methods - Part 1: basidiomycetes. XP CEN/TS 15083-1. European Committee for Standardization: Brussels, Belgium.

CEN. 2012. EN 117: Wood preservatives - Determination of toxic values against Reticulitermes species (European termites) (Laboratory method). European Committee for Standardization: Brussels, Belgium.

CEN. 2013. EN 335: Durability of wood and wood-based products - Use classes: definitions, application to solid wood and wood-based products. European Committee for Standardization. Brussels, Belgium.

CEN. 2016. EN 350: Durability of wood and wood-based products - Testing and classification of the durability to biological agents of wood and wood-based materials. European Committee for Standardization. Brussels, Belgium.

De Oliveira-Araújo, S.; Vital B.R.; Oliveira, B.; de Cássia Oliveira Carneiro, A.; Lourenço, A.; Pereira, H. 2016. Physical and mechanical properties of heat treated wood from Aspidosperma populifolium, Dipteryx odorata and Mimosa scabrella. Maderas-Cienc Tecnol 18(1): 143-156. http://dx.doi.org/10.4067/ S0718-221X2016005000015.

De Souza, R.C.; Fernandes, J.B.; Vieira, P.C.; Da Silva, M.F.D.F.; Godoy, M.F.P.; Pagnocca, F.C.; Bueno, O.C.; Hebling, M.J.A.; Pirani, J.R. 2005. A new imidazole alkaloid and other onstituents from Pilocarpus grandiflorus and their antifungal activity. Z Naturforsch 60(7): 787-791. https://doi.org/10.1515/ znb-2005-0715.

Dilik T.; Hiziroglu, S. 2012. Bonding strength of heat treated compressed Eastern red cedar wood. Mater Design 42: 317-320. https://doi.org/10.1016/j.matdes.2012.05.050.

Doi, S.; Takahashi, M.; Yoshimura, T.; Kubota, M.; Adachi, A. 1998. Attraction of steamed Japanese larch (Larix leptolepis (Sieb. et Zucc.) Gord.) heartwood to the subterranean termite Coptotermes formosanus Shiraki (Isoptera: Rhinotermitidae). Holzforschung 52(1): 7-12. https://doi.org/10.1515/hfsg.1998.52.1.7

Esteves, B.; Graça, J.; Pereira, H. 2008. Extractive composition and summative chemical analysis of thermally treated eucalypt wood. Holzforschung 62(3): 344-351. https://doi.org/10.1515/HF.2008.057

Esteves, B.; Pereira, H.M. 2009. Wood modification by heat treatment: a review. BioResources 4(1): 370-404. https://ojs.cnr.ncsu.edu/index.php/BioRes/article/view/BioRes_04_1_\%23\%23\%23\%23_Esteves_P_Wood_Mod_Heat_Treatment.

Esteves, B.; Videira, R.; Pereira, H. 2011. Chemistry and ecotoxicity of heat-treated pine wood extractives. Wood Sci Technol 45(4): 661-676. https://doi.org/10.1007/s00226-010-0356-0.

Gao, Y.; Wang, H.; Guo, J.; Peng, P.; Zhai, M.; Shed, D. 2016. Hydrothermal degradation of hemicelluloses from triploid poplar in hot compressed water at 180-340 ${ }^{\circ}$ C. Polym Degrad Stab 126: 179-187. https:// doi.org/10.1016/j.polymdegradstab.2016.02.003.

Gérard, J.; Guibal, D.; Paradis, S.; Cerre, J.; Thévenon, M.; Thibaut, A. ; Brancheriau L. ; Gandon, 
G. ; Guyot, A.; Langbour, P.; Lotte, S.; Marchal, R.; Martin, P.; Thibaut, B.; Vernay, M.; Amusant, N.; Baudassé, C.; Boutahar, N.; Cabantous, B.; Gérard, C.; Méjean, C.; Mouras, S.; Troalen, N.; Vialle, M.; Volle, G.; Zaremski, A.; Baillères, Henri.; Beauchêne, J.; Boyer, F.; Calchera, G.; Candelier, K.; Daigremont, C.; Fouquet D.; Gallet, P.; Koese, S.; Leménager, N.; Martin, L. ; Napoli, A. ; Pignolet, L. ;Pinta, F.; Roda, J.; Sales, C.; Valière, P. 2017. Tropical timber atlas. Versailles : Ed. Quae, 999 p. (Guide pratique: Quae). ISBN 978-2-7592-2770-9. https://agritrop.cirad.fr/586531/.

Gérardin, P. 2016. New alternatives for wood preservation based on thermal and chemical modification of wood-a review. Ann For Sci 73(3): 559-570. https://doi.org/10.1007/s13595-015-0531-4.

Guo, H.; Bachtiar, E.; Regal, J.R.; Heeb, M.; Schwarze, F.W.M.R.; Burgert, I. 2018. Non-biocidal preservation of wood against brown-rot fungi with TiO2/Ce Xerogel. Green Chem 20(6): 1375-1382. https:// doi.org/10.1039/C7GC03751A.

Hakkou, M.; Pétrissans, M.; Gérardin, P.; Zoulalian, A. 2006. Investigation of the reasons for fungal durability of heat-treated beech wood. Polym Degrad Stabil 91(2): 393-397. https://doi.org/10.1016/j.polymdegradstab.2005.04.042.

Hannouz, S.; Collet, R.; Buteaud, J.C.; Bléron, L.; Candelier, K. 2015. Mechanical characterization of heat treated ash wood in relation with structural timber standards. Pro Ligno 11(2): 3-10. http://www.proligno. ro/ro/articles/2015/2/hannouz.pdf.

Ibrahim, M.N.M.; Sriprasanthi, R.B.; Shamsudeen, S.; Adam, F.; Bhawani, S.A. 2012. A concise review of the natural existence, synthesis, properties, and applications of syringaldehyde. BioResources 7(3): 4377-4399. https://ojs.cnr.ncsu.edu/index.php/BioRes/article/view/BioRes_07_3_Ibrahim_SSAB_Review_ Synthesis_Properties_Applications_Syringaldehyde.

Inari, G.; Petrissans, M.; Lambert, J.; Ehrhardt, J.J.; Gerardin, P. 2007. Chemical reactivity of heat-treated wood. Wood Sci Technol 41(2): 157-168. https://doi.org/10.1007/s00226-006-0092-7.

International Thermowood Association. 2003. ThermoWood handbook. Helsinki, Finland. https:/www. thermowood.fi/.

Kamdem, D.; Pizzi, A.; Triboulot, M.C. 2000. Heat-treated timber: potentially toxic by-products presence and extent of wood cell wall degradation. Holz Roh Werkst 58(4): 253-257. https://doi.org/10.1007/ s001070050420.

Kamdem, D.P.; Pizzi, A.; Jermannaud, A. 2002. Durability of heat-treated wood. Holz Roh Werkst 60(1): 1-6. https://doi.org/10.1007/s00107-001-0261-1.

Kadir, R.; Awang, K.; Khamaruddin, Z.; Soit, Z. 2015. Chemical compositions and termiticidal activities of the heartwood from Calophyllum inophyllum L. Ann Brazil Acad Sci 87(2): 743-751. http://dx.doi. org/10.1590/0001-3765201520140041.

Kelly, C.; Jones, O.; Barnhart, C.; Lajoie, C. 2008. Effect of furfural, vanillin and syringaldehyde on Candida guilliermondii; Growth and xylitol biosynthesis. In Biotechnology for Fuels and Chemicals. ABAB Symposium (Part A: Enzyme Engineering and Biotechnology). Adney, W.S.; McMillan J.D.; Mielenz J.; Klasson K.T. (eds). Humana Press: 615-626. https://doi.org/10.1007/978-1-60327-526-2_57.

Lekounougou, S.; Pétrissans, M.; Jacquot, J.P.; Gelhaye, E.; Gérardin, P. 2009. Effect of heat treatment on extracellular enzymatic activities involved in beech wood degradation by Trametes versicolor. Wood Sci Technol 43(3-4): 331-341. https://doi.org/10.1007/s00226-008-0236-z.

Lima, T.A.; Pontual, E.V.; Dornelles, L.P.; Amorima, P.K.; Sá, R.A.; Breitenbach Barroso Coelho, L.C.; Napoleão, T.H.; Guedes Paiva, P.M. 2014. Digestive enzymes from workers and soldiers of termite Nasutitermes corniger. Comp Biochem Phys B 176: 1-8. https://doi.org/10.1016/j.cbpb.2014.07.001.

Lovaglio, T.; D'Auria, M.; Rita, A.; Todaro, L. 2017. Compositions of compounds extracted from thermo-treated wood using solvents of different polarities. iForest 10(5): 824-828. https://doi.org/10.3832/ ifor2360-010. 
Mantanis, G.I. 2017. Chemical modification of wood by acetylation or furfurylation: A review of the present scaled-up technologies. BioResources 12(2): 4478-4489. https://ojs.cnr.ncsu.edu/index.php/BioRes/ article/view/BioRes_12_2_Mantanis_Review_Chemical_Modification_Wood_Acetylation.

Metä-Kortelainen, S.; Anitikainen, T.; Viitaniemi, P. 2005. The water absorption of sapwood and heartwood of Scots pine and Norway spruce heat-treated at $170^{\circ} \mathrm{C}, 190^{\circ} \mathrm{C}, 210^{\circ} \mathrm{C}$ and $230^{\circ} \mathrm{C}$. Holz Roh Werkst 64(3): 192-197. https://doi.org/10.1007/s00107-005-0063-y.

Momohara, I.; Ohmura, W.; Kato, H.; Kubojima, Y. 2003. Effect of high temperature treatment on wood durability against the Brown-rot fungus, Fomitopsis palustris, and the termite, Coptotermes formosanus. In Proceedings of $8^{\text {th }}$ International IUFRO Wood Drying Conference: 284-287. Brasov, Romania.

Murugesan, K.; Yang, I.H.; Kim, Y.; Jeon, J.; Chang, Y. 2009. Enhanced transformation of malachite green by laccase of Ganoderma lucidum in the presence of natural phenolic compounds. App Microbiol Biot 82(2): 341-350. https://doi.org/10.1007/s00253-008-1819-1.

Niemz, P.; Hofmann, T.; Rétfalvi, T. 2010. Investigation of chemical changes in the structure of thermally modified wood. Maderas-Cienc Tecnol 12(2): 69-78. http://dx.doi.org/10.4067/S0718-221X2010000200002.

NIST. 2011. NIST 11 MS Database and MS Search Program v.2.0g. U.S. Department of Commerce, National Institute of Standards and Technology Standard Reference Data Program, Gaithersburg, MD 20899, USA.

Nunes, L.; Nobre, T.; Rapp, A. 2004. Thermally modified wood in choice tests with subterranean termites. COST E37, Reinbeck, IA, USA.

Pal, M.; Verma, R.K.; Tewari, S.K. 2011. Anti-termite activity of essential oil and its components from Myristica fragrans against Microcerotermes beesoni. Journal of Applied Sciences and Environmental Management 15(4): 597-599. https://www.ajol.info/index.php/jasem/article/view/88610.

Peters, J.; Pfriem, A.; Horbens, M.; Fischer, S.; Wagenführ, A. 2009. Emissions from thermally modified beech wood, their reduction by solvent extraction and fungicidal effect of the organic solvent extracts. Wood Mater Sci Eng 4(1-2): 61-66. https://doi.org/10.1080/17480270903340562.

Poncsak, S.; Kocaefe, D.; Simard, F.; Pichette, A. 2009. Evolution of extractive composition during thermal treatment of jack pine. J Wood Chem Technol 29(3): 251-264. https://doi.org/10.1080/02773810902928582.

Purich, D.L. 2010. Factors influencing enzyme activity. In Enzyme kinetics: catalysis and control: a reference of theory and best-practice methods: 379-484. Purich, D.L. (Ed.) Elsevier. https://doi.org/10.1016/ B978-0-12-380924-7.10007-9.

Qin, L.; Li, W.C.; Liu, L.; Zhu, J.Q.; Li, X.; Li, B.Z.; Yuan, Y.J. 2016. Inhibition of lignin-derived phenolic compounds to cellulose. Biotechnol Biofuels 9: 70-80. https://doi.org/10.1186/s13068-016-0485-2.

Regnault-Roger, C.; Ribodeau, M.; Hamraoui, A.; Bareau, I.; Blanchard, P.; Gil-Munoz, M.I.; Barberan, F.T. 2003. Polyphenolic compounds of Mediterranean Lamiaceae and investigation of orientational effects on Acanthoscelides obtectus (Say). J Stored Prod Res 40(4): 395-408. https://doi.org/10.1016/S0022474X(03)00031-6.

Rousset, P.; Perré, P.; Girard, P. 2004. Modification of mass transfer properties in poplar wood ( $P$. robusta) by thermal treatment at high temperature. Holz Roh Werkst 62(2): 113-119. https://doi.org/10.1007/ s00107-003-0459-5.

Rowell, R.M.; Pettersens, R.; Han, J.S.; Rowell, J.S.; Tshabalala, M.A. 2005. Cell wall chemistry. In Handbook of wood chemistry and wood composites. Chapter 3: 35-72. Rowell, R. (ed.). CRC Press, Boca Raton, FL, USA. https://www.fs.usda.gov/treesearch/pubs/42245.

Salem, N.; Msaada, K.; Elkahoui, S.; Mangano, G.; Azaeiz, S.; Ben Slimen, I.; Kefi, S.; Pintore, G.; Limam, F.; Marzouk, B. 2014. Evaluation of Antibacterial, Antifungal, and Antioxidant Activities of Safflower Natural Dyes during Flowering. BioMed Res Int 762397, 10p. https://doi.org/10.1155/2014/762397. 
Salman, S.; Pétrissans, A.; Thévenon, M.F.; Dumarçay, S.; Gérardin, P. 2016. Decay and -termite resistance of pine blocks impregnated with different additives and subjected to heat treatment. Eur J Wood Prod 74(1): 37-42. https://doi.org/10.1007/s00107-015-0972-3.

Salman, S.; Thévenon, M.F.; Pétrissans, A.; Dumarçay, S.; Candelier K.; Gérardin, P. 2017. Improvement of the durability of heat-treated wood against termites. Maderas-Cienc Tecnol 19(3): 317-328. http://dx.doi.org/10.4067/S0718-221X2017005000027.

Sandberg, D.; Kutnar, A. 2016. Thermal Modified Timber (TMT): Recent development in Europe and North America. Wood Fiber Sci 48: 28-39. https:/wfs.swst.org/index.php/wfs/article/view/2296.

Sandberg, D.; Kutnar, A.; Mantanis, G. 2017. Wood modification technologies - a review. iForest 10: 895-908. https://doi.org/10.3832/ifor2380-010.

SAS Institute. 2012. JMP 10.0.2 program. SAS Institute Inc. Cary, NC, USA.

Schultz, T.P.; Nicholas, D.D.; Preston, A.F. 2007. A brief review of the past, present and future of wood preservation. Pest Manag Sci 63(8): 784-788. https://doi.org/10.1002/ps.1386.

Sivrikaya, H.; Can, A.; Teresa de Troya, M.C. 2015. Comparative biological resistance of differently thermal modified wood species against decay fungi, Reticulitermes grassei and Hylotrupes bajulus. MaderasCienc Tecnol 17(3): 559-570. http://dx.doi.org/10.4067/S0718-221X2015005000050.

Surini, T.; Charrier, F.; Malvestio, J.; Charrier, B.; Moubarik, A.; Castéra, P.; Grelier, S. 2012. Physical properties and termite durability of maritime pine Pinus pinaster Ait., heat-treated under vacuum pressure. Wood Sci Technol 46(1): 487-501. https://doi.org/10.1007/s00226-011-0421-3.

Susi, P.; Aktuganov, G.; Himanen, J.; Korpela, T. 2011. Biological control of wood decay against fungal infection. J Environ Manage 92(7): 1681-1689. https://doi.org/10.1016/j.jenvman.2011.03.004.

Tjeerdsma, B.F.; Militz, H. 2005. Chemical changes in hydrothermal treated wood: FTIR analysis of combined hydrothermal and dry heat treated wood. Holz Roh Werkst 63(2): 102-111. https://doi.org/10.1007/ s00107-004-0532-8.

Vallet, C.; Alvez, E.; Mila, I.; Pollet, B.; Weiland, J.; Guyonnet, R.; Lapierre, C. 2001. Retification of maritime pine: lignin structure and wood properties (In French). In Les Cahiers scientifiques du bois. Volume 2. Arbolor. Quatrième journée Forêt-Bois, ENSTIB, Epinal. Association des sciences et technologies du bois, Nancy, France. 176p.

Wang, W.; Cao, J.; Cui, F.; Wang, X. 2012. Effect of ph on chemical components and mechanical properties of thermally modified wood. Wood Fiber Sci 44(1): 46-53. https://wfs.swst.org/index.php/wfs/article/ view/1700.

Wang, Z.; Yang, X.; Sun, B.; Chai, Y.; Liu, J.; Cao, J. 2016. Effect of Vacuum Heat Treatment on the Chemical Composition of Larch Wood. BioResources 11(3): 5743-5750. https://ojs.cnr.ncsu.edu/index.php/ BioRes/article/view/BioRes_11_3_5743_W.

Weiland, J.J.; Guyonnet, R. 2003. Study of chemical modifications and fungi degradation of thermally modified wood using DRIFT spectroscopy. Holz Roh Werkst 61(3): 216-220. https://doi.org/10.1007/s00107003-0364-y.

Ximenes, E.; Kim, Y.; Mosier, N.; Dien, B.; Ladisch, M. 2011. Deactivation of cellulases by phenols. Enzyme Microb Technol 48(1): 54-60. https://doi.org/10.1016/j.enzmictec.2010.09.006.

Yalcin, M.; Sahin, H.I. 2015. Changes in the chemical structure and decay resistance of heat-treated narrow-leaved ash wood. Maderas-Cienc Tecnol 17(2): 435-446. http://dx.doi.org/10.4067/S0718$221 \mathrm{X} 2015005000040$

Yildiz, S.; Gezer, D.; Yildiz, U. 2006. Mechanical and chemical behavior of spruce wood modified by heat. Build Environ 41(12): 1762-1766. https://doi.org/10.1016/j.buildenv.2005.07.017. 
Yu, Z.; Gwak, K.S.; Treasure, T.; Jameel, H.; Chang, H.; Park, S. 2014. Effect of lignin chemistry on the enzymatic hydrolysis of woody biomass. ChemSusChem 7(7): 1942-1950. https://doi.org/10.1002/ cssc. 201400042 . 